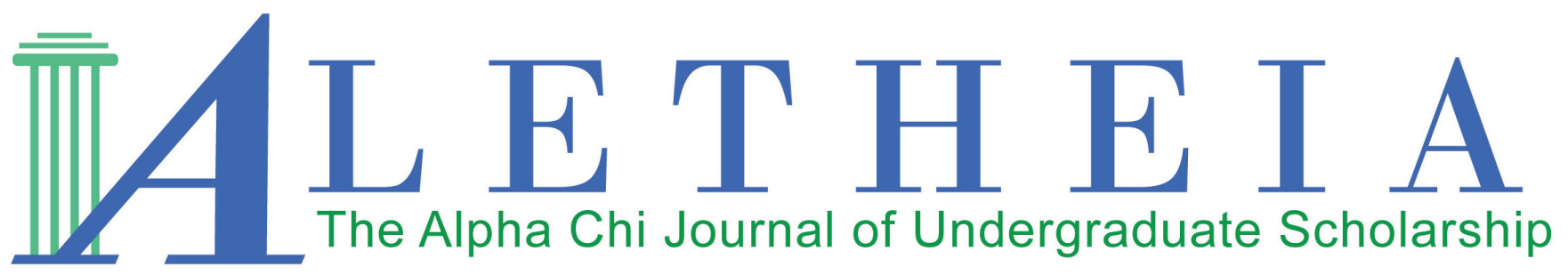

Volume 3 | Issue 1 | 2018

\title{
The Iran Nuclear Deal: The Influence of Congressional Speeches on Public Opinion
}

\author{
Nicole Mirkazemi \\ California State University, Bakersfield \\ California Iota Chapter
}

Vol. 3(1), 2018

Article Title: The Iran Nuclear Deal: The Influence of Congressional Speeches on Public Opinion

DOI: $10.21081 / \mathrm{AX} 0119$

ISSN: $2381-800 \mathrm{X}$

Key Words: Iran Nuclear Deal, congressional speeches, public opinion, legislator's influence This work is licensed under a Creative Commons Attribution 4.0 International License.

Author contact information is available from the Editor at editor@alphachihonor.org.

\section{Aletheia-The Alpha Chi Journal of Undergraduate Scholarship}

- This publication is an online, peer-reviewed, interdisciplinary undergraduate journal, whose mission is to promote high quality research and scholarship among undergraduates by showcasing exemplary work.

- Submissions can be in any basic or applied field of study, including the physical and life sciences, the social sciences, the humanities, education, engineering, and the arts.

- Publication in Aletheia will recognize students who excel academically and foster mentor/mentee relationships between faculty and students.

- In keeping with the strong tradition of student involvement in all levels of Alpha Chi, the journal will also provide a forum for students to become actively involved in the writing, peer review, and publication process.

- More information and instructions for authors is available under the publications tab at www.AlphaChiHonor.org. Questions to the editor may be directed to editor@alphachihonor.org.

\footnotetext{
Alpha Chi is a national college honor society that admits students from all academic disciplines, with membership limited to the top 10 percent of an institution's juniors, seniors, and graduate students. Invitation to membership comes only through an institutional chapter. A college seeking a chapter must grant baccalaureate degrees and be regionally accredited. Some 300 chapters, located in almost every state, induct approximately 11,000 members annually. Alpha Chi members have been "making scholarship effective for good" since 1922.
} 


\title{
The Iran Nuclear Deal: The Influence of Congressional Speeches on Public Opinion
}

\author{
Nicole Mirkazemi \\ California State University, Bakersfield \\ California Iota Chapterr
}

\begin{abstract}
The Iran Nuclear Deal, an agreement between Iran, the U.S., and five other countries, was established to block Iran from nuclear weapons. This research examines whether congressional speeches affect public opinion regarding the deal. Congressional Republicans have proposed a rejection of the deal; Democrats have blocked it. Studies exist involving the effects on public opinion; however, they only examine certain influences. This study will expand past research by looking at a new variable: congressional speeches. A content analysis was performed on 83 congressional speeches that were given from July 14, 2015, to January 16,2016 , to identify whether they contain negative language. Three public opinion polls were collected from both before and after the above timeframe. The results show a change in public opinion on this deal. The bigger picture is this: if public opinion shifts, legislators that should be representing us may also be influencing the way we think.
\end{abstract}

Key words: Iran Nuclear Deal, congressional speeches, public opinion, legislator's influence

\section{Introduction}

"Nuclear physicists, military officials, nonproliferation experts, and more than 100 countries across the globe have all voiced their support for the Iran Nuclear Deal" (The Historic Deal, 2015). The Joint Comprehensive Plan of Action (JCPOA), or the Iran Nuclear deal, is an agreement between Iran, the United States, China, Germany, France, Russia, and the United Kingdom. It blocks any path from Iran to a nuclear weapon, specifically a bomb. It establishes a $98 \%$ reduction on the country's supply of uranium, reduces the number of centrifuges, or machines that create uranium for bombs, from 20,000 to 6,104 , redesigns the Arak Reactor so no "weapons-grade plutonium" is produced, and allows the IAEA (International Atomic Energy Agency) to inspect and monitor their nuclear program, verifying that no material disappears (The Historic Deal, 2015). The most critical issue with this deal is the lifting of sanctions on Iran. This will essentially give Iran access to the very same resources that would allow them to create a nuclear weapon (The White House, 2015).

The 113th/114th U.S. Congress had mixed feelings on the deal, with same-party legislators divided. Harry Reid (D-NV), now retired, publicly supported the deal with Iran while Charles Schumer (D-NY), rejected it (Davenport, 2015 p. 27). Marco Rubio (R-FL) formally showed his opposition towards the deal as well as major House and Senate Republicans. A majority of Democrats 
in the 113th/114th Congress blocked the resolution brought up by Republicans to reject the deal (Barrett, 2015). If Congress is split on the issue, how does public opinion vary? Studies have shown that public opinion varies based on political affiliation (Bolsen, 2014), but do congressional leaders negatively affect the views of the people? This research explores the impact that members of Congress have on public opinion.

\section{Research Question, Hypothesis, and Expectations}

This research seeks to contribute to past literature by exploring whether members of Congress affect the United States' public opinion on the Iran Nuclear Deal. The legislative branch, made up of the two chambers of Congress, was created by the Founders as a more direct link from the government to the people. The Founders had the intention that government leaders would derive their power from the people. The connection between Congress and the people does not appear to be as close as anticipated by the Founders (The U.S. National Archives and Records Administration). One option in verifying this is to see if Congress's decisions or speeches have an effect on the views of the public regarding the Iran deal. Congressional decisions can be vague, divided, and too broad to examine; for this reason, we will concentrate on congressional speeches which shall include speeches made during congressional sessions, televised interviews, and press releases. One of the most intense conflicts in Congress that has created a divide is the JCPOA, or the Iran Nuclear Deal. This deal serves as a perfect piece of legislation to utilize in this paper because of how recent and divisive it is. Therefore, this paper asks, what effect do congressional speeches have on American public opinion in relation to the Iran Nuclear Deal? The hypothesis is that congressional speeches on the Iran Nuclear Deal containing more negativity will translate into lower levels of public support on the deal, as seen and correlated in public opinion polls. Due to a large amount of spoken negativity on this deal by fellow legislators, there is sufficient data available to explore this hypothesis. One blatant example of this spoken negativity came from former House Speaker John Boehner. On one occasion, he asserted that the Iran deal, "hands Iran billions to support more of their terrorist activities..." (Speaker Boehner's Press Office, 2015).

The hypothesis is expected to be supported. In an article written by Klein (2015), the President's speech on the Iran deal is discussed. President Obama gave a speech in support of the nuclear deal; however, his speech was said to have unnecessary partisan rhetoric. The article then looks at public support on the deal; a July opinion poll on support for the Iran deal, conducted by Public Policy Polling, shows 54\% of Americans in support of the deal. This poll was taken before Congress voted and debated the deal in September (Klein, 2015) and opened the floor to the dismissive attitudes of congressional leaders. This debate had yet to occur at the time the above poll was taken; therefore, there was less controversy available to influence the public. This could possibly account for $54 \%$ of the American public supporting the deal. It seems as though the more support (or negativity) the public sees and hears from its leaders on the deal, the more positive (or negative) its views of it are.

A decrease in public support of the Iran Nuclear Deal is expected, partially due to the increased divide in Congress on the agreement, but more importantly, due to the speeches given by congressional leaders. It is not the fact that there is a divide currently in Congress, it is the idea that the divide is politically based and that it is making noise. It is receiving media attention that is then put through a lens and relayed to the public. Recently, Congress has attempted to pass a resolution to block the deal from going through. Multiple speeches from our congressional representatives are in newspapers, on the television, and online via social media. These speeches emphasize the increasingly negative views the majority of congressional leaders have regarding the deal. Due to this intense action, I expect to see a decrease in public support.

There appears to be a divide among the public that reflects the views of congressional members' political affiliations. For example, because there is a substantial number of Republican members of Congress against the deal, an elevated number of Republicans in the public that share this opposing view is expected. Congress is divided on the deal with Democrats blocking Republicans from rejecting the deal. This emphasizes each side's view on this foreign policy issue with the majority of Republicans against it and the majority of Democrats in support of it (Barrett, 2015). It's not expected that all Republicans will be against the deal; however, a decent majority should appear to be following in the footsteps of their leaders. A past study has already shown that political parties affect public opinion. In this study, 
researchers found that public opinion is influenced by political party; however, the main research was centered on the question of how parties motivate public opinion (Leeper, 2014).

\section{Theoretical Framework}

Representatives in government are elected for a vital reason: to represent our voices at the federal level "Political representation occurs when political actors speak, advocate, symbolize, and act on behalf of others in the political arena" (Dovi, 2006). The Delegate Theory of Representation mirrors this belief, asserting that a politician's duty or purpose in office is to be the voice of the people (Mccrone and Kukinski, 1979). The constituents may influence the legislators in one way or another, but when important legislation is discussed in Congress before the people, does it affect or poison the well? When a constituent's respective legislator or any same-party representative discusses a piece of legislation, giving their view on the issue, does he or she affect the way the public views that issue? The theory taken from this study is that speeches in strong support of a specific side affect the public's views. This theory is supported by past research; in a study completed by Wald (1992), the Bishop's Peace Pastoral reinforced peace not war. After being exposed to this, public opinion surveys showed an increase in the support for peace. Key speeches that take a side on an issue have been seen to influence public opinion, but does the type of authoritative figure matter? In Wald's study, the Bishop, a religious leader, was seen influencing public opinion. In this study, we are employing similar strategies to explore whether congressional leaders have that similar effect on the public.

In the study on congressional speeches affecting public opinion on this foreign policy issue, the independent variable is congressional speeches and the dependent variable is public opinion on the Iran deal. In the same academic work executed by Wald (1992), the variables used were the Bishop's Peace Pastoral and public opinion. This study justifies the reasoning behind the choice for these variables; it clearly emphasizes the idea that there is a linkage between religious speeches and public opinion on peace and opens the door to a similar study on whether other key speeches affect the public's view on different pieces of legislation (Wald, 1992). Public opinion is a legitimate dependent variable. It verifies this idea that certain speeches can affect public views by placing a speech or letter as the independent variable. In justifying why this research is explored, I would like to highlight the prior scholarship completed regarding this topic. Although there has been research executed surrounding the effects of public opinion, there has yet to be any research completed on congressional speeches affecting the views of the public on controversial foreign policy issues. I would like to further the field of political science by exploring these possible factors influencing public opinion. It is important to note the reasoning behind the subject selection of a foreign policy issue. There has been an abundance of research completed on the unstable nature of public opinion on foreign policy issues. In particular, Ole Holsti, an American political scientist, discussed Gabriel Almond's research regarding public opinion. Almond found that public opinion is highly volatile on international issues. The public lacks interest on foreign policy issues in part due to its limited attention span. Holsti takes this further, explaining that public opinion becomes focused on foreign policy during wars, crises, confrontations, or threats. When these issues go away, so does public opinion on them (Holsti, 2005). The Iran Nuclear deal is a hot topic because of the threat Iran poses in relation to nuclear weapons. The deal falls in line with Holsti's categorization of a threat. Due to a general lack of knowledge on international issues, the public's opinion is unstable and thus susceptible to influence. This provides an appropriate setting for determining whether congressional leaders can establish such influence.

The media is a possible intervening variable. A common link between congressional speeches and public opinion is the vehicle through which the public hears about this speech. Congressional speeches are televised through the use of the media. The media captures the news, alters the information, and puts it through a lens for the public to view it in a certain way. The manner in which these congressional speeches are televised and discussed explains the relationship between congressional speeches (the independent variable) and public opinion (the dependent variables) by emphasizing the way the public is exposed to the speeches. In a study conducted on presidential speeches affecting public opinion, the media was also seen as a possible influence. This study conducted research that looked into what effect the media had on the view of 
the public on presidential speeches (Young and Perkins, 2005). In this study, the media is not seen distorting congressional leaders' messages on the deal. Regarding the congressional speeches given on the House or Senate floors, the media, if at all covering these speeches, simply puts forth transcripts. When looking at the televised interviews or press releases, the media is seen as more of an intervening variable. However, the media is not profoundly influencing the public. Instead, it is used as a vehicle to get messages across to the public. In some cases, the media is essentially seen summarizing their overall messages. In a separate study, placing this in perspective, the media is seen as an essential third actor in the information flow from elites to the public (Baum and Potter, 2008). Another possible intervening variable is political affiliation. This explains the connection between congressional speeches and public opinion by highlighting one major component that the congressman and congresswoman giving the speech and the citizen viewing and agreeing with the speech have in common: their political party. Rarely will you see a Democratic member of Congress strongly influencing a Republican citizen. This goes back to the study that concluded that political affiliation did have an influence on public opinion (Catalini, Roarty, \& Bell, 2013). This study justifies the use of political affiliation as an intervening variable by pointing out that Democrats, members of Congress or not, tend to influence other Democrats in the American public. It shows that amid the connection between congressional speeches and public opinion lies a commonality that helps the public identify the member of Congress they are willing to listen to: their political affiliation.

\section{Literature Review}

Past research on this subject is still developing. A study regarding the specific influence of congressional leaders on public opinion was not found in past literature. Due to this absence, I will instead look to research most similar to the current study conducted. One of the most relatable studies is Kenneth D. Wald's (1992). He conducted an analysis on the effects the United States Catholic Bishop's 1983 pastoral, The Challenge of Peace: God's Promise and our Response (a document advocating the end of nuclear proliferation) had on public opinion. In this study, Religious Elites and Public Opinion: The Impact of the Bishops' Peace
Pastoral, Wald hypothesized that the pastoral would have the intended effect on American public opinion, specifically with Catholics demonstrating a decrease of support of nuclear proliferation and defense spending (Wald, 1992). Wald discussed a few limitations he encountered; the first limitation was insufficient data available to conduct thorough research. Other than the GALLUP poll, no other poll had asked directly about the pastoral. Wald's study also set limitations on the impacts of public opinion to a religious effect (Wald, 1992). This research study furthers the field to include a politically based impact and examines additional effects on public opinion.

A separate study was conducted by Shanahan, Mcbeth, and Hathaway (2011) regarding the effect or impact policy narratives have on public opinion. It was hypothesized that policy narratives are becoming increasingly important in affecting public opinion. This study took a sample of 194 students and had them take a pretest and a posttest after being exposed to media reports on a controversial issue in Yellowstone. The policy issue concerned snowmobile access in the winter months. The results showed the narratives having an effect on public opinion strengthening "congruent" opinions and converting decisions to the opposite of prior held opinions (Shanahad et al., 2011). This study limited the field by only looking at the effect narratives had regarding the Yellowstone controversy. This issue was not as critical or historic as major pieces of legislation. This confines the study to a national and social issue. Although the study does bring up two sides on the issue, a national federalist approach and a compact federalist approach, it limits the field to a social policy: whether snowmobiles should be strictly regulated (the national federalist approach) or loosely regulated (the compact federalist approach) (Shanahad et al., 2011). It raises the question of whether policy narratives can also influence public opinion on more profound, high-priority policies. This research study looks at a foreign policy issue; it furthers the field by looking at a more profound, international issue: the Iran Nuclear Deal. This is being discussed at the federal level by our representatives in government, possibly affecting the safety of citizens in all 50 states.

Prior research has touched on multiple effects on public opinion. One study on policy adoption displayed the impacts it had on public opinion. The researchers implemented a survey before and after an Iowa 
Supreme Court decision on same-sex marriage. The study found that there was an increase of support for same-sex marriage after the positive decision was made (Kreitzer, Hamilton, \& Tolbert, 2014). This shows yet another impact on public opinion; however, this study focuses on more of a judicial effect, thus failing to show a congressional related impact, a significant limitation. This study also limits the impact to a national issue: same-sex marriage. The work presented in this article furthers the field in two ways: first, it expands the effects on public opinion past the judiciary and second, it shows the impacts on an international and foreign relations issue: the Iran Nuclear Deal.

Other past research shows a majority of Americans supporting the Iran Nuclear Deal. It displays poll findings of Americans. Constituents of certain political affiliations support the Iran Nuclear Deal (Hartley, 2015). It emphasizes the impact one's political party could have on his or her opinion. Another study also describes the effect political affiliation has on public opinion on this particular deal. This study shows the reasoning behind Democrats and Republicans in choosing to support or oppose the Iran Nuclear Deal. Democrats tend to believe that diplomacy is a key component for the U.S. and Iran, and Republicans tend to base their opposition on their distrust for President Obama (Catalini, Roarty, \& Bell, 2013). Because a large quantity of research has been dedicated to the effects political affiliation has on public opinion, my research extends both of these research studies and the field by looking into another effect when it comes to public opinion on the Iran Nuclear Deal: congressional speeches.

In researching presidential influence on public opinion, Matthew Eshbaugh-Soha analyzed the literature on the topic, finding that presidential persuasion does not ultimately have the capacity to change or alter public opinion. Instead, it reinforces current beliefs on topics. In the instance it does, it is merely attributed to the specific issue, which must not have been previously salient to the public. Although former President Obama spoke in favor of the Iran Nuclear deal, his rhetoric may not have an impact in changing the public's views on this deal. With this information in mind, rather than requiring a control for the president's influence, we instead can expect a reinforcement of current beliefs on the deal. Instead of focusing on presidential persuasion, a topic with an abundance of prior research, examining congressional speeches will expand current research on whether there are additional effects on the American public's opinions or not.

\section{Methodology}

This study is part of a comparison between legislators and public opinion on the Iran Nuclear Deal. It measures the approval or disapproval of public opinion on the Iran deal in relation to the positive or negative speech given in the time interval of when the deal was proposed to when it was implemented. This timeframe is from July 14, 2015, to January 16, 2016. This work only examines congressional speeches that were given within this timeframe because this is the specific time allotted to Congress to debate the nuclear deal (Congressional Research Service 2015; Joint Comprehensive Plan of Action, 2016). It is also the period that congressional leaders will be highlighted in regards to what their opinions are on the JCPOA. A qualitative content analysis approach was utilized to carry out this study. Qualitative methods use nonnumerical data. It is an industry standard to use a content analysis when analyzing language. When analyzing speeches, or any text for that matter, one of the benefits of a qualitative content analysis, is a rich and nuanced understanding of the data pool (Neuendorf, 2002). By using this approach in conjunction with well developed coding schemes, precision and accuracy enhance the study (Noriega, 2013).

Furthermore, a summative approach to content analysis was employed in this research because the study was dealing with negative language, its frequency, and how it was utilized in the speeches. Summative content analysis is the identifying and quantifying of certain words to explore the usage rather than infer a meaning (Hsieh and Shannon, 2005). This approach goes on to understand an underlying meaning of the content. In this research, it is meant to understand the use of the negative language in regards to the Iran deal. In this study, hand-coding was used to code the 83 speeches. Although hand-coding has a few drawbacks, in this study, each speech was coded four times to ensure accuracy and reliability. "The success of a content analysis depends greatly on the coding process" (Hsieh and Shannon, 2005). The goal of this research is to assist in determining if congressional speeches have an effect on public opinion in relation to the Iran Nuclear Deal. This method is utilized because it fits the objective 
of this study. In order to answer the research question, subjects must be interviewed across the nation. This can only be done in an effective manner through public opinion polls. Three public opinion polls given both before and after the time the speeches were delivered were used in this research. The first public opinion poll used in this study, Declining Support for Iran Nuclear Deal, was conducted by the Pew Research Center from September 3-7, 2015. The second is untitled but was conducted by the University of Maryland's Program for Public Consultation and its Center for International Security Studies on September 1, 2015. The final public opinion poll used in this study, Americans' Views on the Iran Nuclear Deal, was conducted by GALLUP from February 3-7, 2016. After performing a content analysis on the speeches, the data was then analyzed and placed into a table based on when the speeches were given. This helps discover if there is indeed a change in public opinion from before to after the speech was given. Employing this approach is efficient, as prior research on public opinion has implemented similar methods, yielding meaningful results. This can be seen in Wald's (1992) work, which is articulated in the literature and theoretical framework discussion above.

The research question was tested by looking at prior public opinion polls that ask something to the effect of whether one supports the Iran Nuclear Deal, or JCPOA. The three public opinion polls, the one by the Pew Research Center, the one by the program at the University of Maryland, and the one by GALLUP, were chosen because of the timeframe they were given in and the question they posed to their subjects. Each public opinion poll gives precise data on the Iran Nuclear Deal during the specified timeframe. The research looked at 83 key speeches made in Congress on the Iran Nuclear Deal from July 14, 2015, to January 16, 2016. Eighty-three is a large quantity of speeches given by congressmen and congresswomen on any one deal which makes this a perfect sample size that avoids any biases. A few congressional leaders who spoke on the deal include: Congressman Kevin McCarthy (R-24rd district of CA), Senator Marco Rubio (R-Fl), Congressman Brad Sherman (D-30th district of CA), Congressman Tom McClintock (R-4th district of CA), Congressman Gene Green (D-29th district of Texas), Senator Jerry Moran (R-KS), Senator Bob Corker (RTN), Congresswoman Martha McSally (R-2nd district of AZ), Congressman Lee Zeldin (R-1st district of NY), and Congressman Ken Calvert (R-42nd district of CA). These ten congressional leaders gave speeches that were emphasized on their websites or in another media source. The other 73 congressional leaders that gave speeches on the JCPOA included 46 Republicans and 37 Democrats. These 83 speeches were then analyzed for negativity on the Iran deal (qualitative approach) to demonstrate the impact they will have on public opinion. Although senators make up a portion of the speeches given on the JCPOA, the majority of the speeches were given by members of the House of Representatives. Since the House was established to be closer to the people, it only makes sense that members of the House would have stronger opinions on a deal that affects their constituents. The majority of these speeches were given on the congressional floor and were televised. Others were made during televised interviews and a small minority were given directly to constituents and placed on the congressman or woman's website. Despite the varying delivery methods of these speeches, they all employed rhetoric that, because of the deal's perceived threat, made the public more susceptible to it (Holsti, 2005). Due to the varying methods of delivery, the public's perception of the controversy surrounding the Iran Nuclear deal may increase in likelihood. These diverse methods allow for more outreach to the public.

The public opinion polls were analyzed around the time the speeches were given, with one being before and the other being after. Two separate polls were used, one in the months of July to September 7th and the other from September to February. The polling or survey data collection method was used where the researcher selects a sample of respondents from a population and administers a questionnaire or when a researcher looks to prior polling or surveying done on the subject.

The first step taken to implement this research was analyzing the speeches members of Congress have given. A content analysis was completed on the speeches to determine if the language was positive or negative regarding the Iran deal. The coding scheme is attached in the appendix and was used based on the success of another study (Busher, 2006). The research looked at whether they were encouraging opposition on the deal or not and also slightly looked at their political affiliation to account for the intervening variable. Key negative words were looked for after a first reading of the speeches. Examples of the negative words looked at include terrorism, nuclear bomb, and nuclear war. 
These negative words or phrases were chosen because they give off a feeling of fear or anger. Although prior studies have shown these words to have a positive effect, given the context of the Iran Nuclear deal and nuclear weapons, these words and phrases can be determined to have a negative effect. According to a study by Lang et al. (2005), patients' ratings of pain and anxiety were measured after their exposure to negative language describing an experience. It was found that negative, not positive, language largely impacts the patients' feelings. The impact negative language has on an individual confirms my reasoning for using it in this study. Various public opinion polls within the timeframe of the Iran deal were categorized as those conducted before and after the time the speeches were given. The research looked for gaps or jumps in the opposition of the deal (lower approval ratings or higher disapproval ratings).

\section{Findings}

Eighty-three key speeches were analyzed throughout this study. Five speeches were made during the months of July or August, after the deal was introduced. These speeches were given by the following members of Congress: Congressman Lee Zeldin's speech at Temple Hillel (Zeldin for Congress, 2015), Congressman Brad Sherman's speech at Valley Beth Shalom in Encino, CA (Press, 2015), Congressman Ron DeSantis's speech (Government Publishing Office, 2015), Congresswoman Ros-Lehtinen's speech (Government Publishing Office, 2015), and Senator Bob Corker's speech (Corker, 2015). The speeches made during the months of September through January 16th include the remaining 78 speeches.
A few of these speeches include: Majority Leader Kevin McCarthy's televised interview (Hewitt, 2015), Congressman Gene Green's speech on the House floor (Green, 2015), Congressman Tom McClintock's speech on the House floor (Newsroom, 2015), Senator Marco Rubio's speech on the Senate floor (Rubio, 2015), and Congressman Ken Calvert's press release (Gagnon, 2015). Out of the 83 speeches analyzed, 46 were from Republicans and 37 were from Democrats. Of the 46 Republicans, 45 of the speeches were negative. Of the 37 Democrats, 7 of the speeches were negative. The total number of negative speeches given is 52 . The negative speeches were split into timeframes and compared to the three public opinion polls. The public opinion poll conducted by the Pew Research Center, Declining Support for Iran Nuclear Deal, was compared with the speeches given between July 2015 to August 2015. The untitled public opinion poll by a program at the University of Maryland and the public opinion poll by GALLUP, Americans' Views on the Iran Nuclear Deal, were both compared with the speeches given between September 2015 to January 16, 2016. Below, Table 1 illustrates the number of negative speeches found in this study.

Five speeches were analyzed for negative language in the late month of July and the entire month of August. Of these five speeches, 109 negative words and phrases were used. Each of the five speeches had an overall negative tone and used compelling negative language such as terrorist, war, or nuclear bomb to emphasize the way each legislator giving the speech felt about the JCPOA. According to Dr. Habib Sadeghi (2016), "Words have power. Their meaning crystallizes

Table 1. Number of Negative Speeches.

\begin{tabular}{|c|c|c|c|}
\hline Date of Speech & Political Affiliation & Type of Speech & \# of Speeches \\
\hline \multirow{3}{*}{ July 2015 to August 2015 } & Republican & Negative & 4 \\
\cline { 2 - 4 } & \multirow{2}{*}{ Democrat } & Positive & 0 \\
\cline { 2 - 4 } & \multirow{2}{*}{$\begin{array}{c}\text { Republican } \\
\text { Sanuary 16, 2016 }\end{array}$} & Negative & 1 \\
\cline { 2 - 4 } & Desitive & 0 \\
\hline & Democrat & Negative & 42 \\
\hline & & Positive & 1 \\
\hline
\end{tabular}

This shows the number of negative speeches that were determined during this study. 


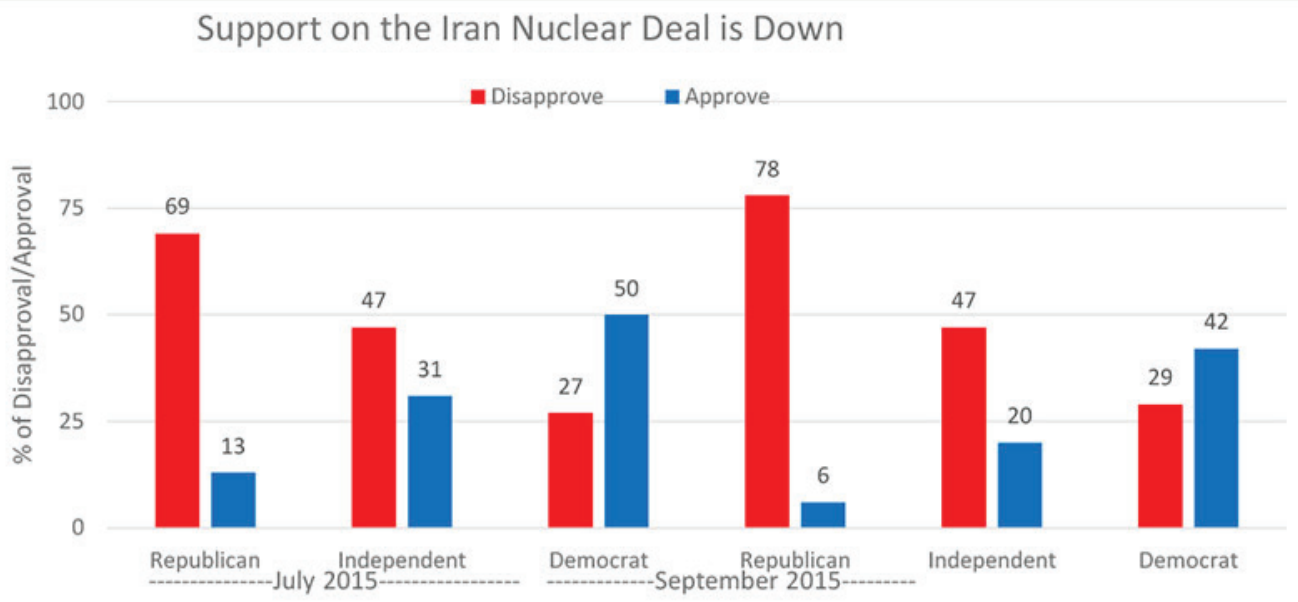

Figure $1^{1}$. Support for the Iran Nuclear Deal is Down.

perceptions that shape our beliefs, drive our behavior, and ultimately, create our world." This emphasizes how big of an effect language has on shaping our beliefs. The way we hear something is directly connected to the emotion we associate with that topic. According to a study conducted on negative language affecting the way people think, the more negative language people hear or see, the more irritation and anger they feel regarding that subject. Negative language is actually seen as having a larger effect (Park, 2015). Given these psychological facts, the 109 negative words and phrases found in these five speeches should affect the views of the public, as our hypothesis states.

From the public opinion poll above (Fig. 1), one can determine that there was a decrease in overall support for the Iran Nuclear Deal during the time these speeches were given. Taking a closer look at the poll, we can see that the political affiliation is also accounted for. This nationally representative sample of 1,004 adults living in the United States had a margin of sampling error of \pm 3.7 percentage points. Sixty-nine percent of Republicans disapproved of the deal in July; that number increased to $78 \%$ in September (PewResearch Center, 2015). Twenty-seven percent of Democrats disapproved of the deal in July and that number increased to $29 \%$ in September. During the late month of July and entire month of August, those five speeches were given by

\footnotetext{
${ }^{1}$ The data used to create this figure was collected by the Pew Research Center; however, the image itself is original (Pew Research, 2015).
}

congressional leaders, all opposing the JCPOA. The negative language used in these speeches had an effect on the public. In July, $50 \%$ of Democrats supported the deal. In September, that number fell to $42 \%$.

\begin{tabular}{|c|c|c|}
\hline Timeframe & $\begin{array}{l}\text { Political } \\
\text { Affiliation }\end{array}$ & $\begin{array}{l}\text { \# of Negative } \\
\text { Words Used }\end{array}$ \\
\hline \multirow{2}{*}{$\begin{array}{l}\text { July } 2015 \text { to } \\
\text { August } 2015\end{array}$} & Republican & 52 \\
\hline & Democrat & 57 \\
\hline \multirow{2}{*}{$\begin{array}{l}\text { September } 7, \\
2015 \text { to January } \\
2016\end{array}$} & Republican & 367 \\
\hline & Democrat & 216 \\
\hline
\end{tabular}

\section{Table $2^{2}$. Number of Negative Words Used.}

The other 78 speeches were given in the months of September, October, November, December, and early January. These speeches contained over 583 negative words and phrases. The public opinion poll below was administered by a program at the University of Maryland from August 17th to the 20th with a sampling size of 702 adults in the United States. The margin of error was \pm 3.7 percentage points. This opinion poll was conducted before any of the 78 speeches were given. At this point, $52 \%$ of the nation polled were in favor of the deal with Iran. Thirty percent of Republicans, $60 \%$ of Independents, and $69 \%$ of Democrats were in favor of it.

\footnotetext{
${ }^{2}$ This is an original table that shows the number of negative words used in all 83 speeches in this study.
} 


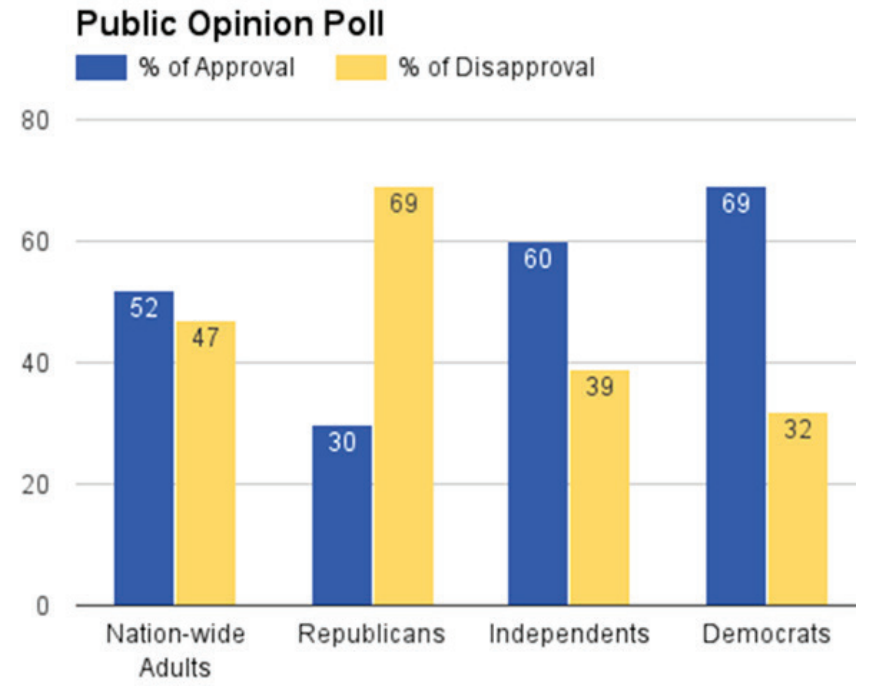

Figure $2^{3}$. Survey on the Approval and Disapproval of the Iran deal among the public.

After these 78 speeches were given by our congressional leaders, the public's views changed. The poll below shows the new approval rating of the deal and was conducted February 3rd through the 7th with a sampling size of 1,021 adults in the United States by the Princeton Survey Research Associates International. A margin of sampling error was not provided. Among the overall nation, the approval rating dropped to $30 \%$. The approval rating among Republicans dropped to $9 \%$, among Independents dropped to $30 \%$, and among Democrats dropped to $51 \%$. After being exposed to so much negative language, more than 580 negative words and phrases, on the deal from their leaders, the result is an increase in the disapproval rating. On September 10, 2015, the House of Representatives debated the deal. More than half of the leaders that spoke were not only opposed to the deal, but had overall negative language throughout their entire speeches. Two hundred and sixty-nine congressional leaders are outright against the deal (Government Publishing Office, 2015). The majority of the congressional leaders against the deal are Republicans. The public opinion poll below mirrors this with $80 \%$ of Republicans opposing the deal. Less than 20 of the speeches that were given were Democrats opposed to the deal. This is also mirrored in the below

\footnotetext{
${ }^{3}$ The data used in this figure was collected from the University of Maryland's Program for Public Consul-tation and the Center of International and Security Studies (USIP, 2016).
}

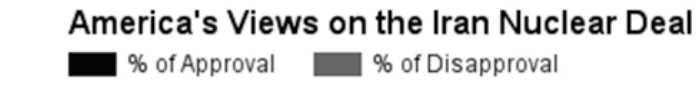

100

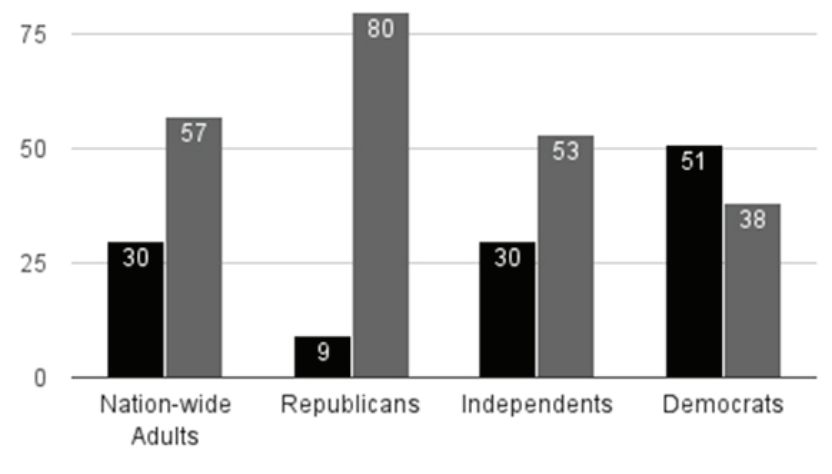

Figure $3^{4}$. America's Views on the Iran Nuclear Deal.

$53 \%$ of Independents, those who do not affiliate with either party, still opposing the deal. Congressional leaders using negative language alone plays a role in their views without political affiliation playing any role. The 83 speeches and the negative language used in them accounts for the decrease in support of the deal among the public.

The hypothesis stands; congressional speeches on the Iran Nuclear Deal that contained more negativity translated into lower levels of public support on the deal. This was seen in both of the above situations. By testing this hypothesis with two different timeframes and two different public opinion polls, the research is more accurate and is less likely due to chance.

\section{Conclusion}

Throughout this study, the change in public opinion from before these speeches were heard by the public to after they were exposed to them was analyzed. The findings of this study put forth important implications. If there is a change in public opinion from before to after exposure, there may be other factors (i.e. congressional speeches) shaping the American public's opinion on specific legislation. The public's views are constantly changing and the results presented here suggest that the

\footnotetext{
${ }^{4}$ The data in this figure was collected among the American public and shows the approval and disap-proval of the Iran Nuclear Deal on February 3-7 of 2016 (USIP, 2016).
} 
speeches analyzed may be the reason for such shifts. This can contribute to the power members of Congress have in influencing legislation. Rather than having the believed influence of the public affecting the way Congress votes, and debates, this research suggests that the legislators that should be representing our views are instead influencing the way we think.

It is difficult to make any major conclusions regarding this research. Before simply concluding that congressional speeches influence public opinion on the Iran Nuclear deal, I must admit that, without exact public opinion polls administered both before and after the congressional speeches, this data might mask important intervening variables, reducing the accuracy of the overall study. With this information intact, this study shall be looked at as more of an exploratory work than conclusive. Due to these drawbacks and/or inconsistencies, this study cannot pose any conclusive results, but the results are suggestive and should be further explored.

A visible influence from Congress was seen on public opinion in relation to the deal. Due to the existence of such a divide on the nuclear deal, this research suggests at least one factor influencing it. Do people really shape their own opinions, or are our opinions just a combination of what we allow to influence us? This is the bigger picture. The public's opinions are a combination of multiple things, one of which may be their congressional leaders' speeches and rhetoric.

In analyzing more than one speech's effect, the findings are less likely to be a result by chance. By looking at previous public opinion polls, possible errors and biases that could have taken place if an original survey was implemented were disregarded.

In analyzing this data from July to August of 2015, I found that Democrats had more spoken negative words in speeches than Republicans. Overall, the Democrats and Republicans in Congress were divided. The results address the polarization that exists between Democrats and Republicans in the U.S. Congress. A recent study affirmed this, “...today's lawmakers increasingly identify with party-defined messages and seek to gain power by advancing within their respective party" (Devins, 2015). It went on to assert that Republicans and Democrats in Congress are distant and are "increasingly unlikely to seek common ground" (Devins, 2015). Two examples of polarization in Congress include the Affordable Care Act and the November 2013 repeal of a filibuster to push
President Obama's nominees (Devins, 2015). The Iran Nuclear Deal can now be included as an example of this polarization.

A few limitations existed in this study. In not securing a research grant, the analysis was not run through a computer assisted coding program; therefore, a well developed hand-coding method was used for the content analysis. Again, a benefit of using the handcoding method is that the researcher is able to be intimate with the study. I was also unable to hire a research assistant which increases my chances of making human error by having to hand code all 83 speeches on my own. However, by implementing the hand-coding method more than once, I was able to reduce the chance of human error. By utilizing nationwide aggregate data, it is also quite challenging to pull data that directly accounts for or relates to the established research question. Although this can be seen as a drawback of using nationwide public opinion polling data, the information extracted from it is well worth it. This essentially allows researchers to utilize completed data to further advance the field and knowledge surrounding these topics. Given the 83 congressional speeches analyzed, it is also important to note that the sample selection, although fairly representative of the congressional make-up, is robust but not random. This too forces the study to be looked at as exploratory rather than conclusive.

Going forward, future research should consider a few different approaches. First, broaden the type of influential leaders used in the study. For example, look to state assemblymen, assemblywomen, and state senators to see if they too have an influence on public opinion. From there, another possibility is to look at different pieces of legislation to further examine our leaders' influence on a wide range of issues. Finally, a good aspect to research is the way the five other countries have felt on the Iran deal. Do their congressional leaders affect the way the public has seen the deal? Future research could look at public opinion polls implemented in their countries and compare it to the way their leaders feel. This would provide clear evidence that all countries have leaders that affect the way their public sees this deal, not just the United States. This could provide evidence that, regardless of the form of government each country has, the leaders of that country may have some influence over the way the public feels on certain deals that are made. 


\section{References}

Barrett, T., Raju, M., Walsh, D., \& LoBianco, T. (2015, September 10). Senate Democrats protect Obama on Iran vote - CNNPolitics.com. Retrieved November 3, 2015.

Baum, M.A., \& Potter, P. B. (2008). The Relationships Between Mass Media, Public Opinion, and Foreign Policy: Toward a Theoretical Synthesis. Annual Reviews, 11(1), 39-65. doi:10.1146/annurev.polisci.11.060406.214132

Bolsen, T., Druckman, J., \& Cook, F. (2014). The influence of partisan motivated reasoning on public opinion. Political Behavior, 36(2), 235-262. doi:10.1007/s11109-0139238-0

Busher, A. B. (2006). Framing Hillary Clinton: A content analysis of the New York Times news coverage of the 2000 New York Senate election. Thesis, Georgia State University. Retrieved from http://scholarworks.gsu. edu/communication theses $/ 10$

Catalini, M., Roarty, A., \& Bell, P. (2013). Poll: should members of your party support or oppose the Iran deal?. $\mathrm{Na}$ tional Journal, 14.

Congressional Research Service. (2015). Legislative Search Results. Retrieved July 11, 2016, from https://www.congress.gov/bill/114th-congress/house-bill/3461?q=07B $\% 22$ search $\% 22 \% 3 \mathrm{~A} \% 5 \mathrm{~B} \% 22 \mathrm{iran}+$ nuclear+deal+first + introduced + july $+14 \% 22 \% 5 \mathrm{D} \% 7 \mathrm{D} \&$ resultIndex $=3$

Corker, B. (2015, August 17). Sen. Bob Corker: Congress should reject the bad Iran deal. Retrieved February 20, 2016, from https:/www.washingtonpost.com/opinions/ congress-should-reject-the-bad-iran-deal/2015/08/17/ 0c983c78-44f3-11e5-8ab4-c73967a143d3_story.html

Davenport, K. (2015). Congress considers Iran deal. Arms Control Today, 45(7), 27-30.

Devins, N. (2015). Measuring Party Polarization In Congress: Lessons From Congressional Participation As Amicus Curiae. Case Western Reserve Law Review, 65(4), 9331026.

Dovi, S. (2006). Political Representation. http://plato.stanford. edu/entries/political-representation/(Accessed August 16, 2016).

Eshbaugh-Soha, Matthew. 2015. "Presidential Persuasion and Public Opinion." Oxford Bibliographies: Political Science. Oxford University Press. DOI: 10.1093/obo/ 9780199756223-0129

Gagnon, J. (2015, September 11). Rep. Calvert votes against Iran deal. Retrieved February 29, 2016, from http:// calvert.house.gov/news/documentsingle.aspx?Documen$\mathrm{tID}=397447$

Government Publishing Office. (2015). Congressional Record House Articles. Retrieved February 20, 2016, from https://www.congress.gov/congressional-record/
Green, G. (2015, September 9). Opposing the Iran deal. Retrieved February 20, 2016, from https:/green.house.gov/ media-center/speeches/iran-deal

Hartley, D. C. (2015). Iran Nuclear Deal backed by majority of Americans. Washington Report On Middle East Affairs, $34(3), 66$.

Hewitt, H. (2015, September 04). GOP Majority Leader Kevin McCarthy on The Iran deal vote: the Hugh Hewitt show. Retrieved February 29, 2016, from http://www. hughhewitt.com/gop-majority-leader-kevin-mccarthyon-the-iran-deal-vote/

Holsti, O. R. (2005). Public opinion and American foreign policy. Ann Arbor, MI: The University of Michigan Press.

Hsieh, H. \& Shannon, S.E. (2005). Three Approaches to Qualitative ContentAnalysis. Qualitative Health Research, 15(9), 1277-1288. doi: 10.1177/1049732305276687

Joint Comprehensive Plan of Action (JCPOA). (2016). Retrieved July 11, 2016, from http://www.state.gov/p/nea/ $\mathrm{rt} / \mathrm{jcpoa} / \mathrm{index} \cdot \mathrm{htm}$

Klein, J. (2015). The Iranian-vote carnival: focus on what happens once the nuclear deal goes through. Time, 186(7), 30.

Kreitzer, R. J., Hamilton, A. J., \& Tolbert, C. J. (2014). Does policy adoption change opinions on minority rights? The effects of legalizing same-sex marriage. Political Research Quarterly, 67(4), 795-808.

Lang, E. V., Hatsiopoulou, O., Koch, T., Berbaum, K., Lutgendorf, S., Kettenmann, E., \& ... Kaptchuk, T. J. (2005). Can words hurt? Patient-provider interactions during invasive procedures. Pain (03043959), 114(1/2), 303-309. doi:10.1016/j.pain.2004.12.028

Leeper, T. J., \& Slothuus, R. (2014). Political parties, motivated reasoning, and public opinion formation. Political Psychology, 35129-156. doi:10.1111/pops.12164

Mccrone, D. J., \& Kuklinski, J. H. (1979). The Delegate Theory of Representation. American Journal of Political Science, 23(2), 278-300. doi:10.2307/2111003

Neuendorf, K. A. (2002). The Content Analysis Guidebook Thousand Oaks: Sage Publications.

Newsroom. (2015, September 10). Retreating from responsibility (Iran Nuclear "Deal"). Retrieved February 20, 2016, from https://mcclintock.house.gov/newsroom/ speeches/retreating-from-responsibility-iran-nuclear-deal

Noriega, C. A., \& Iribarren, F. J. (2013). Toward an empirical analysis of hate speech on commercial talk radio. Harvard Journal Of Hispanic Policy, 2569-96.

Park, C. S. (2015). Applying "negativity bias" to twitter: negative news on twitter, emotions, and political learning. Journal Of Information Technology \& Politics, 12(4), 342-359. doi:10.1080/19331681.2015.1100225 
Pew Research Center. (2015, September 08). Support for Iran Nuclear agreement falls. Retrieved March 06, 2016, from http://www.people-press.org/2015/09/08/supportfor-iran-nuclear-agreement-falls/

Press. (2015, September 2). Congressman Brad Sherman speech on Iran Nuclear agreement. Retrieved February 20, 2016, from https://sherman.house.gov/media-center/ press-releases/congressman-brad-sherman-speech-oniran-nuclear-agreement

Press Release. (2015, September 14). U.S. Rep. McSally speaks out against, opposes dangerous Iran deal. Retrieved February 20, 2016, from https://mcsally.

house.gov/media-center/press-releases/us-rep-mcsallyspeaks-out-against-opposes-dangerous-iran-deal

Rozin, P., Berman, L., \& Royzman, E. (2010). Biases in use of positive and negative words across twenty natural languages. Cognition \& Emotion, 24(3), 536-548. doi: 10.1080/02699930902793462

Rubio, M. (2015, September 10). U.S. Senator for Florida, Marco Rubio. Retrieved February 29, 2016, from http:// www.rubio.senate.gov/public/index.cfm/press-releases?ID=e4eb5a76-cb51-45d1-8ca3-6ac99a58417b

Sadeghi, H. (2016). The scary power of negative words. Retrieved February 21, 2016, from http://goop.com/thescary-power-of-negative-words/

Shanahan, E. A., Mcbeth, M. K., \& Hathaway, P. L. (2011). Narrative policy framework: The influence of media policy narratives on public opinion. Politics \& Policy, 39(3), 373-400. doi:10.1111/j.1747-1346.2011.00295.x

Speaker Boehner's Press Office. (2015, September 11). Speaker Boehner: This Iran Deal is Far Worse Than Anything I Imagined. Retrieved July 13, 2016, from http://www.speaker.gov/speech/speaker-boehner-irandeal-far-worse-anything-i-imagined

The Historic Deal that will prevent Iran from acquiring a nuclear weapon. (2015). Retrieved November 13, 2015, from https://www.whitehouse.gov/issues/foreign-policy/ iran-deal

The U.S. National Archives and Records Administration. The Declaration of Independence: A Transcription. Retrieved September 10, 2016, from http://www.archives.gov/ exhibits/charters/declaration_transcript.html

The White House. (2015, August 04). Joint Comprehensive Plan of Action - The Iran deal. Retrieved February 20, 2016, from https://medium.com/the-iran-deal/joint-comprehensive-plan-of-action-5cdd9b320fd\#.y4z54otu6

United States Senator Jerry Moran. (2015, September 22). Retrieved February 29, 2016, from http://www.moran. senate.gov/public/index.cfm/speeches? ID $=34 \mathrm{~b} 67$ ceda53b-451b-a69e-873754ef9834

USIP. (2016). US public opinion on Iran deal. Retrieved February 20, 2016, from http://iranprimer.usip.org/blog/ 2015/sep/01/us-public-opinion-iran-deal
Wald, K. (1992). Religious elites and public opinion: The impact of the bishops' peace pastoral. Review Of Politics, 54(1), 112.

Young, G., \& Perkins, W. B. (2005). Presidential rhetoric, the public agenda, and the end of presidential television's "golden age". Journal Of Politics, 67(4), 1190-1205. doi:10.1111/j.1468-2508.2005.00356.x

Zeldin for Congress. (2015, July 23). Rep. Lee Zeldin Iran nuke deal speech at Temple Hillel - July 19, 2015. Retrieved February 29, 2016, from https://www.youtube.c om/watch?v=kyvETaoeYuo 


\section{Appendix A}

\section{Coding Instructions}

Record the date the speech was given as month/day/year. For example, August 5, 2015 would be 08/05/2015.

Record the type of congressional work it is.

Record which House of Congress the work came from.

Record the first and last name of the congressman/congresswoman who spoke on the Iran deal. After recording his or her name, record the gender of the congressman/congresswoman.

Record the topic of the work.

Record the number of pages the congressional work is.

If the work is not written, write " 0 " and answer the following question: How long was the speech? Use the format, hours:minutes:seconds.

For each article, record whether the speaker has a positive, neutral, or negative tone. Analyze each speech by looking for words that have a negative connotation. Words or phrases that connote a sense of fear, anger, or those that portray the country in a bad light are examples of negativity. Words or phrases that show a sense of approval, reassurance, or that portray the country in a good light are examples of positivity. If the words and phrases used by the speakers do not show negativity or positivity, they are considered neutral and shall be labeled as such. 


\section{Appendix B}

\section{Coding Sheet}

I will be coding for phrases. I will not have a pre-defined number set of categories to code for; this allows for flexibility. Irrelevant text such as "and," "the," "a," "an," etc. will be ignored when coding.

What is the date of publication?

What type of congressional work is it?

Speech

Televised Interview

Newspaper Article

Other,

Which Chamber of Congress did the individual giving the speech come from?

The House of Representatives

The Senate

What is the name of the Congressman/Congresswoman?

A.
B.
- Male
-Female

What is the topic of this work?

Iran relations

Iran Nuclear Deal

Middle East

Other

How many pages is the work?

*If the work is not written, just write 0 and answer the following question.

How long was the work?

What was the overall stance of the text?

Positive $=3$

Neutral $=2$

Negative $=1$

What the speech is support of the deal?

Yes

No 